\title{
The Neurotoxic Effects of Artemether on the Cytoarchitecture of the Trapezoid Nuclei of Adult Male Wistar Rats (Rattus novegicus)
}

\author{
Efectos Neurotóxicos del Artemeter sobre la Citoarquitectura del Núcleo Trapezoide \\ en Ratas Machos Adultas Wistar (Rattus novegicus)
}

"Akinlolu Abdulazeez Adelaja; **Olatunde Owoeye \& *Adedayo Bewaji Ejiwunmi

\begin{abstract}
ADELAJA, A. A.; OWOEYE, O. \& EJIWUNMI, A. B. The neurotoxic effects of artemether on the cytoarchitecture of the trapezoid nuclei of adult male Wistar rats (Rattus novegicus). Int. J. Morphol., 24(4):535-540, 2006.

SUMMARY: In Man, artemether is given at $160 \mathrm{mg} / \mathrm{kg} / \mathrm{bodyweight} \mathrm{for} \mathrm{three} \mathrm{days} \mathrm{in} \mathrm{the} \mathrm{treatment} \mathrm{of} \mathrm{malarial.} \mathrm{This} \mathrm{study}$ investigated the effects of corresponding $1.23 / \mathrm{mg} / \mathrm{kg} / \mathrm{bodyweight} \mathrm{of} \mathrm{artemether} \mathrm{for} \mathrm{a} \mathrm{period} \mathrm{of} \mathrm{seven} \mathrm{days} \mathrm{on} \mathrm{the} \mathrm{trapezoid} \mathrm{nuclei} \mathrm{and} \mathrm{the}$ behavioural functions on day 7 after drug administration in rats. This study observed no gross or morphological differences between the two groups of animals (control and experimental groups) on day 7 at the completion of experimental procedure. A significant statistical increase in average body weight was observed in the control groups $\mathrm{C} 1$ (which received only standard diet and water) and C2 (which received $1.23 \mathrm{mg} / \mathrm{kg} /$ bodyweight of normal saline intramuscularly in addition to standard diet and water) from $140-+19.65 \mathrm{~g}$ on day 1 to $146+19.90 \mathrm{~g}$ on Day 1 and $151+12.0 \mathrm{~g}$ on Day 1 to $156.2+12.2 \mathrm{~g}$ on Day 7 respectively. There was a non-statistically significant apparent reduction in body weight in the experimental group $\mathrm{E}$, (which received intramuscular injection of $1.23 \mathrm{mg} / \mathrm{kg} / \mathrm{bodyweight} \mathrm{of}$ artemether) from $160+9.0 \mathrm{~g}$ on Day 1 to $157.4+8.0 \mathrm{~g}$ on Day 7. The assessment of brainstem nuclei showed patchychromatic appearance of neurons of the trapezoid nuclei in the experimental group as against the normal vesicular appearance of neurons of the trapezoid nuclei in the Control Group C. The rats in the control groups CI and C2 displayed normal balance and co-ordination, while rats in the experimental group $\mathrm{E}$, showed abnormalities of balance and co-ordination. Using t-test analysis technique at $95 \%$ confidence interval i.e $\mathrm{t}<$ 0.05 and $\mathrm{P}$ - value $=2.26$, no significant difference was observed between the average brain weight in the control groups $\mathrm{C} 1$ and $\mathrm{C} 2$ and the experimental group $\mathrm{E}$.
\end{abstract}

KEY WORDS: Trapezoid nuclei; Neurotoxic effects; Cytoarchitecture; Rats.

\section{INTRODUCTION}

The Qinghaosu (Artemisinin) is an active antimalaria ingredient isolated from the leaves of a medicinal herb, the Artemisia Annua (Shen et al., 1996). The product has demonstrated marked schizonticidal activity on Plasmodii, including the multi-drug resistant strains of Plasmodium falciparum (Klayman, 1985). Artemisinin is an antimalarial agent with a chemical structure unlike any other. It has no nitrogenous heterocycle. (Schimid et al., 1983). It acts on the growth of the early "ring" stages of the trophozoites of Plasmodium falciparum and ensures rapid clearance of blood parasitaemia (Kombila et al., 1995). Chemical modifications of Artemisinin (reduction plus etherification) have enabled more potent and more soluble derivatives to be obtained. Among these different products is artemether. (Paluther®), the methyl ether form of dihydroartemisinin (Luo et al., 1984).
In the year 2006, the Federal Ministry of Health adopted the usage of artemisinin derivatives as the most potent antimalarial drugs for the treatment of malaria in Nigeria. The new policy of the Nigerian government also recommended that chloroquine containing products should no longer be used for the treatment of malaria. In spite of the toxic effects of chloroquine, it remained the mainstay of malaria treatment until the advent of resistant parasites. Similarly, it is important to establish the toxic effects of Artemisinin through clinical and morphological studies for appropriate therapeutic use.

In the last two decades, more than two million patients have been treated with artemisinin or one of its derivatives (artesunate or artemether), predominantly in China and Southeast Asia and more recently in Africa. (Shen et al.,

\footnotetext{
* Department of Anatomy, Faculty of Basic Medical Sciences, Olabisi Onabanjo, University, Ogun State, Nigeria

** Department of Anatomy, Faculty of Basic Medical Sciences, University of Ibadan, Oyo State, Nigeria.
} 
1989). The general toxicity profile in experimental animals has been good. However, in all mammal species tested to date, these compounds have produced an unusual selective pattern of damage to certain brain stem nuclei i.e precerebellar nuclei of the medulla oblongata and particularly those involved in auditory processing and vestibular functions i.e the trapezoid nucleus, the gigantocellular reticular nucleus and the inferior cerebellar peduncle. In the rat, the target brainstem nucleus consistently and most severely affected is the nucleus of the trapezoid body. (Li et al., 2002, Apichart, 2000, and Brewer et al., 1994).

Changes in the affected neurons were loss of Nissl substance, perikaryonal swelling, margination of the nucleus (nucleus eccentricity), nucleolar changes, and increased perikaryonal eosinophilia with occasional clumping of eosinophilic debris. More severe cases had bilateral lesions in other brainstem nuclear groups and a subjective reduction in the normal neuron numbers present compared with vehicle controls. (Brewer et al.; Apichart and Li et al.). All mice with neuropathologic changes also showed behavioral changes as well as loss of co-ordination of balance and equilibrum. (Apichart et al.). In some mice with gait disturbance, no corresponding histopathologic damage could be detected suggesting that there might be a reversible component to artemether neurotoxicity. (Apichart et al.).

The trapezoid nuclei is functionally related to the auditory and vestibular systems, which regulate body balance and equilibrium. (West, 1995). The aims of this study, therefore, were to investigate and evaluate the neurotoxic effects of $1.23 \mathrm{mg} / \mathrm{kg} /$ bodyweight of artemether on the trapezoid nuclei and behavioural functions on day 7 after the completion of experimental procedure.

\section{MATERIAL AND METHOD}

Twenty adult male Wistar rats, weighing between $120 \mathrm{~g}$ and $180 \mathrm{~g}$, were obtained from the animal house of the Department of Veterinary Physiology and University of Ibadan, Nigeria. The rats were acclimatized for a period of seven days in the Department of Anatomy of University of Ibadan, Nigeria. Ethical approval was sought and received from the Department of Anatomy of University of Ibadan on the need to observe completely the rules guiding the employment of rats for scientific studies. The rats were kept five in a cage and fed with standard rat diet purchased from Ladokun and Sons Ltd. in Ibadan daily. All rats were fed with water ad libitum. The drug, artemether (Paluther ${ }^{\circledR}$ ) used in this study was obtained as $8 \%$ solution for intramuscular injection i.e. $80 \mathrm{mg}$ artemether preserved in $1 \mathrm{ml}$ of Arachis (vehicle) oil from May and Baker Nigeria Ltd of Oba Akran Avenue, Ikeja, Lagos State. Normal Saline and Urethane solution (a sedative solution) was obtained from Danax Pharmaceutical Company of Mokola, Ibadan, Oyo State, Nigeria.

The rats were divided into two groups comprising ten rats each namely; experimental group designated Group E and a control group designated Group C. Group E comprised of ten male rats. Each rat was identified by further designations as $\mathrm{E}$ a to $\mathrm{J}$. The total dosage regimen of artemether employed in the treatment of malaria in a $70 \mathrm{Kg}$ adult man is $480 \mathrm{mg} / \mathrm{kg} /$ bodyweight. Thus, rats (weighing between $120 \mathrm{~g}$ and $180 \mathrm{~g}$ ) in Group E were each injected with corresponding $1.23 \mathrm{mg} / \mathrm{kg}$ / bodyweight of artemether for a period of seven consecutive days. No rat was injected with Arachis Oil used as vehicle for preserving the drug (artemether). This was because Arachis Oil had earlier been proved not to have any neurotoxic effect on rats in earlier studies, Li et al., and was also not available as a drug product in Nigeria.

Rats in Group C were further subdivided into Groups $\mathrm{C} 1$ and $\mathrm{C} 2$ with each comprising five rats. Each of the five male rats in Group C1 was coded a - e. Rats in Group C1 were fed with standard diet and water only. The rats were neither injected intramuscularly with artemether nor normal saline. Rats in Group C2 were each injected with $1.23 \mathrm{mg} /$ $\mathrm{kg} /$ bodyweight of normal saline for a period of seven consecutive days. This was to scientifically confirm whether the results observed in the experimental Group E is not as a result of induced stress in the rats during intramuscular injection of $1.23 \mathrm{mg} / \mathrm{kg}$ bodyweight of artemether. Normal Saline is an isotonic medium and thus has no effects on the body tissues. Rats injected with $1.23 \mathrm{mg} / \mathrm{kg} /$ bodyweight of normal saline are thus exposed to the same level of induced stress as rats in the experimental Group E. Each rat was identified by further designated as $\mathrm{C} 2$ a to $\mathrm{e}$.

All rats were sacrificed on day 7 for neurohistopathologic examination. The rats were sedated by intramuscularly injecting each rat with $1 \mathrm{mg}$ of Urethane solution (a sedative solution). Urethane has no known neurotoxic effects on rat brains (Meneguz et al., 1999 ). The rats were then individually sacrificed using a sharp laboratory knife. A necropsy was performed and the head and cranium were carefully removed, avoiding pressure on the underlying brain. The head and exposed brain were immersed in fresh $10 \%$ formalin solution and the brain remained in situ for seven days before its removal from the skull to avoid swelling up of the brain specimens and consequent enzymatic actions on the brain tissues. 
The neurotoxic effects of artemether on the cytoarchitecture of the trapezoid nuclei of adult male Wistar rats. Int. J. Morphol., 24(4):535-540, 2006.

Table I. Mean body weight of rats in control groups C1, C2 and experimental group E on day 1 and day 7.

\begin{tabular}{cccc}
\hline Rats Groups & Mean body Weight (day1) g & Mean body Weight (day 7) g & p - Value \\
\hline C1 & $140 \pm 19.65$ & $146.0 \pm 19.9$ & 2.78 \\
C2 & $151 \pm 12.0$ & $156.2 \pm 12.2$ & 2.78 \\
E & $160 \pm 8.0$ & $157.4 \pm 8.0$ & 2.26 \\
\hline
\end{tabular}

Table II. Brain weight of rats in the control groups $\mathrm{C} 1, \mathrm{C} 2$ and experimental group $\mathrm{E}$ after the completion of experimental procedure.

\begin{tabular}{ccc}
\hline Rats groups & Mean brain weight $(\mathrm{g})$ & $\mathrm{p}$ - value \\
\hline $\mathrm{C} 1$ & $2.12 \pm 0.10$ & \\
$\mathrm{C} 2$ & $2.11 \pm 0.16$ & 2.26 \\
$\mathrm{E}$ & $1.71 \pm 0.11$ & \\
\hline
\end{tabular}

Brainstem tissues were histologically investigated at three levels from midbrain to hinbrain; (A) midbrain to pons (B) pons to the nucleus of hypoglossal nerve and (C) nucleus of hypoglossal nerve down to the hindbrain. Staining of the sections was carried out by employing the Cresyl Violet (VOGT's) Method for Nissl Substance (Carleton, 1967).

The gross parameters measured and the instruments used include:

(i) The normal/abnormal morphological appearance of the brain.

(ii) Weight of the animals using a Swiss microwa balance (type 7720).

(iii)Weight of the brain using a Kertz' precision weighing balance.

The microscopic parameters measured and the methods used include:

(i) The normal/abnormal morphological appearance of the trapezoid nuclei.

(ii) The density of the trapezoid nuclei using a binocular Leitz' microscope with graticum attached to the eye piece.

Assessment of balance and coordination. A standardized assessment of gait (balance and coordination) and fine coordination skills (as described by Apichart et al.) was recorded twice after the completion of the 7 -day injection schedule. Movements of the rats along the horizontal edge of a $9 \mathrm{~mm}$ wide and $100 \mathrm{~cm}$ long brown wooden box for five steps after the completion of experimental procedure on Day 7 were observed. The following were noted and scores accorded respectively: (a) whether the rat was
Table III. Density of damaged trapezoid nuclei in the control groups C1, C2 and experimental group E. 1,062 X.

\begin{tabular}{lcc}
\hline Rats groups & Density of damaged & $\mathrm{p}$ - value \\
\hline Control group C1 & $0.12 \pm 0.01$ & 2.78 \\
Control group C2 & $0.32 \pm 0.01$ & \\
Experimental group E & $1.28 \pm 0.15$ & \\
\hline
\end{tabular}

unsteady i.e. a body angle $>50$ from the vertical axis (a score of 1), (b) hind legs slipping off the edge when walking for five steps (a score of 2) or (c) whether the rat fell twice or more (a score of 3 ) or (d) could not walk at all (a score of 4). There were four outcomes: normal throughout, reversible neurologic abnormality, irreversible abnormality or death. (Apichart et al.). The total obtained scores by each rat was divided by the total obtainable score of 10 i.e $(1+2$ $+3+4=10$ ). Rats with a score result of 0 were designated as Normal and having a steady gait while rats with a score result of $0.5-1.0$ were designated as abnormal and having an unsteady gait and poor balance coordination and rats with a score result of $0.2-0.4$ as slightly abnormal.

\section{RESULTS AND DISCUSSION}

Gross observations: Animal appearance. No gross differences were observed between the two groups of animals on day 7 at the completion of experimental procedure. The brain (with its component parts) of rats in both the control and experimental groups appeared morphologically normal.

Body Weight (Table I): The average body weight in each of Groups C1, C2 and E were calculated on day 1 and day 7 of experimental procedures. Using t-test analysis technique at $95 \%$ confidence interval i.e $\mathrm{t}<0.05$ and $\mathrm{p}$ value $=2.78$, there was a significant increase in body weight between day 1 and day 7 in both control groups $\mathrm{C} 1$ and $\mathrm{C} 2$. The observed slight decrease in body weight from $160 \pm$ $8.0 \mathrm{~g}$ on day 1 to $157.4 \pm 8.0 \mathrm{~g}$ on day 7 in rats of Group $\mathrm{E}$ (Table I) could be due to the negative effects of $1.23 \mathrm{mg} /$ 
$\mathrm{kg} / \mathrm{bodyweight}$ of artemether on normal processes of metabolism with consequent depletion of body protein contents in rats of experimental Group E. However, using t-test analysis technique at $95 \%$ confidence interval i.e $\mathrm{t}<$ 0.05 and $\mathrm{p}$ - value $=2.26$, there was no significant decrease in body weight between day 1 and day 7 in the Experimental Group E.

Brain Weight (Table II): Using t-test analysis technique at $95 \%$ confidence interval i.e $\mathrm{t}<0.05$ and $\mathrm{p}-$ value $=2.78$, no significant difference was observed between the average brain weights of Control Groups C1 and C2. Similarly, using t-test analysis technique at $95 \%$ confidence interval i.e $\mathrm{t}<$ 0.05 and $\mathrm{p}-$ value $=2.78$, no significant difference was observed between the average brain weight of the Control groups C1 and C2 (Table II) and the Experimental Group E.

Microscopic observations of the trapezoid nuclei. Histological assessment of brainstem nuclei showed damage to the trapezoid nucleus in the Experimental Group. The nuclei stained dark as against staining purple in a normal cell. The neurons of the trapezoid nuclei in the Experimental Group E were patchychromatic, unlike the open vesicular appearance of the Control Group C. Such damage indicates neuropathologic lesions, chromatolysis and necrosis.

Density of damaged trapezoid nuclei. The density of damaged trapezoid nuclei was estimated in a field of X $(0.0$ to $1.0 \mathrm{~mm}$ ) per section and in a total of five sections per animal in each of the rats in the Control Groups C1, C2 and the Experimental Group E. The total calculated density per rat was divided by five in the Control Groups C1, C2 and by ten in the Experimental Group E to calculate the mean of the calculated total. The average density of damaged trapezoid nuclei was calculated as $0.12 \pm 0.01,0.32 \pm 0.01$ and $1.28 \pm 0.15$ in the Control Groups C1, C2 and the Experimental Group E, respectively. Using t-test analysis technique at $95 \%$ confidence interval i.e $\mathrm{t}<0.05$ and $\mathrm{p}-$ value $=2.78$ and 2.26, no significant difference was observed between the density of damaged trapezoid nuclei in the Control Groups C1 and C2; while a significant difference was observed between the density of damaged trapezoid nuclei in the Control Groups C1, C2 and the Experimental Group E.

Presence of damaged neurons of trapezoid nuclei in the Control Group C1 could be due to effects of aging or stress, (Table III). Similarly, presence of damaged neurons of trapezoid nuclei in the Control Group C2 (Table III) could be due to the effects of induced stress on the brains of the rats during intramuscular injection of $1.23 \mathrm{mg} / \mathrm{kg} /$ bodyweight of normal saline leading to the expression of stress/heat shock proteins such as $\mathrm{c}-$ fos, $\mathrm{c}-$ jun and hsp 70 (Marc et al., 1995). The increase in density of damaged neurons of trapezoid nuclei in the Experimental Group E compared with the Control Groups $\mathrm{C} 1$ and $\mathrm{C} 2$ could be due to histopathological effects of intramuscular administration of $1.23 \mathrm{mg} / \mathrm{kg} / \mathrm{bodyweight} \mathrm{of} \mathrm{artemether,} \mathrm{which} \mathrm{resulted} \mathrm{in}$ the neurons of the trapezoid nuclei appearing patchychromatic.

Assessment of balance and coordination. Rats in the control Groups C1 and C2 showed normal display of balance and co-ordination. However, in the Experimental Group E, the rats showed abnormalities of balance and co-ordination. All rats in control Groups C1 and C2 had a score of 0, with a steady normal balance and coordination. In the Experimental Group E, six rats fell three times and had a score result of 0.6 while three rats fell twice with a score result of 0.3 and one rat fell only once and had a score result of 0.3 . These observations could probably be due to presence of lesions in the brainstem nuclei i.e the trapezoid nuclei associated with vestibular and balance functions.

This study concludes that the observable potential neurotoxicity of artemisinin derivatives i.e artemether and artesunate are of serious concern and should be considered in the clinical use of these drugs. Earlier studies observed that neither auditory evoked potentials nor any other neurophysiologic assessment had been validated as sensitive predictors of neuronal damage by these drugs. It may never be possible to be absolutely sure that currently used treatment regimens with artemisinin derivatives are completely safe. Loss of few neurons would be impossible to detect (Van Vugt et al., 2000). Thus, it is advisable that artemether be employed only in cases of acute malarial infection. Oral forms of artemether should be employed in the treatment of malaria as against the usage of intramuscular or intravenous forms which had been shown to produce more neurotoxicity in experimental animals. (Gordi et al., 2004). More specifically, the rectal administration of artemether should be employed in clinical use; as it had been shown to be efficacious as other forms in the clearing of blood parasitaemia, and safer than other forms of administration. (Ambroise-Thomas, 1999).

Further studies should be carried out using animal models i.e rats to examine the neurotoxic effects of artemether (at low doses such as 1.25 to $25 \mathrm{mg} / \mathrm{kg}$ / bodyweight as used in man) on the trapezoid nuclei and other brainstem nuclei using the electron microscopy to show fine details which might not be observable using the light microscope. Also, the developments of sensitive physiologic tests for which the results in experimental animals correlate with neuropathologic changes are needed. 
ADELAJA, A. A.; OWOEYE, O. \& EJIWUNMI, A. B. Efectos neurotóxicos del artemeter sobre la citoarquitectura del núcleo trapezoide en ratas macho adultas (Rattus novegicus). Int. J. Morphol., 24(4):535-540, 2006.

RESUMEN: En el Hombre, el artemeter es dado en el tratamiento de la malaria en dosis de $160 \mathrm{mg} / \mathrm{kg}$ de peso, por tres días. Este estudio abordó los efectos de un tratamiento con artemeter, durante 7 días (en dosis de 1,23 $\mathrm{mg} / \mathrm{kg}$ de peso) sobre el núcleo trapezoide de ratas y las funciones de conducta, en el día 7 después de la administración de la droga. No se observaron ni macro ni diferencias morfológicas entre dos grupos de animales (grupos control y experimental) en el día 7 de la completación del procedimiento. Un incremento estadísticamente significativo en el promedio del peso del cuerpo fue encontrado en el grupo control C1 (el que recibió solamente una dieta standard y agua) y C2 (que recibió $1,23 \mathrm{mg} / \mathrm{kg}$ de peso de solución salina intramuscular agregada a la dieta y al agua) que fue desde $140 \pm 19,65$ g y $146 \pm 19,9$ g en el día 1 , respectivamente y de $151 \pm 12$ g y de 156,2 $\pm 12,2$ g en el día 7, respectivamente. No hubo una reducción aparente estadísticamente significativa en el peso del cuerpo del grupo experimental (el cual recibió inyección intramuscular de $1,23 \mathrm{mg} / \mathrm{kg}$ de peso de artemeter), la que fue desde $160 \pm 9 \mathrm{~g}$ en el día 1 y de 157,4 \pm , en el día 7 . La evaluación de núcleos del tronco encefálico mostró apariencia cromática irregular de las neuronas del núcleo trapezoide en el grupo experimental contrariamente a la apariencia vesicular normal de las neuronas de este núcleo en el grupo control. Las ratas de los grupos controles C1 y C2 presentaron un normal balanceo y coordinación, mientras que las ratas del grupo experimental, mostraron anormalidades de balanceo y coordinación. Usando el test $\mathrm{t}$ con $95 \%$ de intervalo de confianza, $\mathrm{p} \leq 0,05$ y con un valor $\mathrm{p}=2,26$, no se observaron diferencias estadísticamente significativas entre el promedio de los grupos $\mathrm{C} 1$ y $\mathrm{C} 2$ y del grupo experimental

PALABRAS CLAVE: Núcleo trapezoide; Efectos neurotóxicos; Citoarquitectura; Ratas.

\section{REFERENCES}

Ambroise-Thomas, P. Current data on major novel antimalaria drugs: Artemisinin (qinghaosu) derivatives. Bull. Acad. Natl. Med., 183(4):797-80, 1999.

Apichart Nontprasert; Sasithon Pukrittayakamee; Marika Nosten-Bertrand; Sirivan Vanijanonta \& Nicholas J, White. Studies of the neurotoxicity of oral artemisinin derivatives in mice. Am. J. Trop. Med. Hgy., 62(3):40912, 2000 .

Brewer, T. G.; Grate, S. J.; Peggins, J. O.; Weina, P. J.; Petras, J. M.; Levine, B, S.; Heiffer, M. H. \& Schuster, B. G. Fatal neurotoxicity of arteether and artemether. Am. Trop. Med. J. Hyg., 51(3):252-9, 1994.

Carleton's Histological Technique. $4^{\text {th }}$. Ed. Toronto, 1967. pp.126-50.

Gordi, T. \& Lepist, E. I. Artemisinin derivatives: toxic for laboratory animals, safe for humans? Toxicol. Lett. 147(2):99-107, 2004.

Klayman, D. L. Qinghaosu (artemisinin): an antimalarial drug from China. Science, 228:1049-55, 1985.

Kombila, M.; Duong, T.; Dufillot, D.; Koko, J.; Guiyedi, V.; Guiguen, C. \& Richard Lenoble, D. L. Alterations morpologiques des hematozoaires de Plasmodium falciparum chez l'enfant gabonaiz traite par artemether. Med. Trop., 55:975-1005, 1995.
Li, G. Q.; Mog, S. R.; Si, Y. Z.; Kyle; Gettayacamin, M. \&. Milhous, K. Neurotoxicity and efficacy of arteether related to its exposure times and exposure levels in rodents. Am. J. Trop. Med. Hyg., 66(5):516$25,2002$.

Luo, X. D.; Bossi, A.; Flippen-Anderson, J. L. \& Gillards, R. The chemistry of drugs. Part IV. Configurations of antimalarials derived from Qinghaosu: dihydroqinghaosu, artemether and artesunic acid. Helv. Chim. Acta, 67 (6):1515-22, 1984.

Marc, A.; Soriano, I. F.; Rodriguez-Farre, E \& Planas, A. M. Expression of $\mathrm{c}-$ fos and inducible hsp - $70 \mathrm{mRNA}$ following a transient episode of focal ischemia that had non - lethal effects on the rat brain. Elsevier. Brain Research, 670:317-20, 1995.

Meneguz, A.; Fortuna, S.; Lorenzini, P. \& Volpe, M.T. Influence of urethane and ketamine on rat hepatic cytochrome $\mathrm{P} 450$ in vivo. Exp. Toxicol. Pathol., 51(45):392-6, 1999.

Schimid, G. \& Hofheinz, W. Total Synthesis of Qinghaosu. J. Am. Chem. Soc., 195:624-5, 1983.

Shen, J. X. ed. Antimalarial drug development in China. Beijing: National Institute of Pharmaceutical Research and Development, 1989. pp. 31-95. 
Shen, J. X. \& Li, G. Q. The history of the development of artemisinin derivatives for antimalarial chemotherapy in China. Hong Kong, Symposium, VII International Conference on Infectious Diseases, June 12, 1996.

Van Vugt, M.; Angus, B. J.; Price, R. N.; Mann, C.; Simpson, J. A.; Poletto, C.; Htoo, S. E.; Looareesuwan, S.; White, N. J. \& Nosten, F. A case-control auditory evaluation of patients treated with artemisinin derivatives for multidrug-resistant Plasmodium falciparum malaria. Am. J. Trop. Med. Hyg. 62(1):65-9, 2000.

West, P. Neurosciences in Medicine. J. P. Lincolt, 1995. pp. 214-24.

\author{
Correspondence to: \\ Dr. Akinlolu Abdulazeez Adelaja \\ Department of Anatomy \\ Faculty of Basic Medical Sciences \\ Olabisi Onabanjo University \\ Remo Campus \\ IKenne \\ Ogun State \\ NIGERIA \\ Phone: $\quad+234-8056454353$ \\ Email:a3laja@yahoo.com \\ a3ade@myself.com
}

Received: 22-04-2006

Accepted: 25-08-2006 